\title{
THE METAMORPHOSES OF FAT
}




\title{
EUROPEAN PERSPECTIVES \\ A Series in Social Thought and Cultural Criticism \\ Lawrence D. Kritzman, Editor
}

\begin{abstract}
European Perspectives presents outstanding books by leading European thinkers. With both classic and contemporary works, the series aims to shape the major intellectual controversies of our day and to facilitate the tasks of historical understanding.
\end{abstract}

For a complete list of books in the series, see pages $263-64$. 


\title{
THE METAMORPHOSES OF

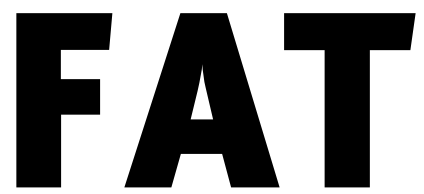

A History of Obesity

\author{
Georges Vigarello
}

Translated from the French by C. Jon Delogu 


\section{COLUMBIA UNIVERSITY PRESS}

Publishers Since 1893

New York Chichester, West Sussex

cup.columbia.edu

\section{Copyright (c) 2013 Columbia University Press}

Georges Vigarello, Les metamorphoses du gras: histoire de l'obésité (Paris: Seuil, 2010) Cet ouvrage a bénéfié du soutien des Programmes d'aide à la publication de l'Institut Français. This work, published as part of a program of aid for publication, received support from the Institut Français.

All rights reserved

Library of Congress Cataloging-in-Publication Data

Vigarello, Georges.

[Métamorphoses du gras. English]

The metamorphoses of fat: a history of obesity / Georges Vigarello; translated from the French by $C$. Jon Delogu.

pages $\mathrm{cm}$.- (European perspectives: a series in social thought and cultural criticism) Includes bibliographical references and index.

ISBN 978-o-231-978-15976-o (cloth: alk. paper); ISBN 978-o-231-53530-4 (e-book)

1. Obesity-Social aspects-History. I. Title.

$$
\begin{array}{cc}
\text { RC628.V5413 } & 2013 \\
362.1963^{\prime} 98-\mathrm{dc} 23 & 2012029197
\end{array}
$$

Columbia University Press books are printed on permanent and durable acid-free paper.

This book is printed on paper with recycled content.

Printed in the United States of America

$$
\begin{aligned}
& \text { c } 10987654321 \\
& \text { p } 10987654321
\end{aligned}
$$

Cover Design: David Drummon

References to Web sites (URLs) were accurate at the time of writing. Neither the author nor Columbia University Press is responsible for URLs that may have expired or changed since the manuscript was prepared. 